\section{Role of Vasopressin in Regulation of Renal Kinin Excretion in Long-Evans and Diabetes Insipidus Rats}

\author{
Michael L. Kauker, Joan T. Crofton, Leonard Share, and \\ Alberto Nasjletti \\ With the assistance of Carolyn Matthews \\ Departments of Pharmacology and Physiology, \\ University of Tennessee Center for the Health Sciences, \\ Memphis, Tennessee 38163
}

bstract. To study the relationship between vasopressin and the renal kallikrein-kinin system we measured the rate of excretion of kinins into the urine of anesthetized rats during conditions of increased and decreased vasopressin level. The excretion of immunoreactive kinins in Brattleboro rats with hereditary diabetes

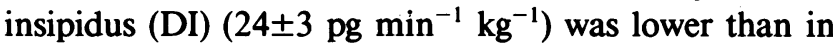
the control Long Evans (LE) rats $\left(182 \pm 22 \mathrm{pg} \mathrm{min}^{-1} \mathrm{~kg}^{-1}\right.$; $P<0.05)$. The DI rats also exhibited negligible urinary excretion of immunoreactive vasopressin, reduced urine osmolality, and increased urine flow and kininogenase excretion. In LE rats, volume expansion by infusion of $0.45 \% \mathrm{NaCl}-2.5 \%$ dextrose to lower vasopressin secretion reduced $(P<0.05)$ kinin excretion, vasopressin excretion, and urine osmolality to 41,26 , and $15 \%$ of their respective control values, while increasing $(P<0.05)$ urine flow and kininogenase excretion. On the other hand, the infusion of $5 \% \mathrm{NaCl}$, which promotes vasopressin secretion, increased $(P<0.05)$ the urinary excretion of kinins and vasopressin to 165 and $396 \%$ of control, while increasing $(P<0.05)$ urine flow and kininogenase excretion. Infusion of vasopressin (1.2 $\mathrm{mU} / \mathrm{h}$, intravenous) enhanced $(P<0.05)$ kinin excretion by two to threefold in DI rats and in $\mathrm{LE}$ rats during volume expansion with $0.45 \% \mathrm{NaCl}-$ $2.5 \%$ dextrose, while decreasing urine flow and increasing urine osmolality. This study demonstrates that the urinary excretion of immunoreactive kinins varies in relation to the urinary level of vasopressin, irrespective of urine volume and osmolality and of the urinary excretions of sodium and kininogenase. The study suggests a role for

Received for publication 17 August 1983 and in revised form 7 November 1983.

J. Clin. Invest.

(c) The American Society for Clinical Investigation, Inc.

0021-9738/84/03/0824/08 $\$ 1.00$

Volume 73, March 1984, 824-831 vasopressin in promoting the activity of the renal kallikrein-kinin system in the rat.

\section{Introduction}

In the kidney, kallikrein and prekallikrein occur in association with the plasma membrane (1) and basolateral membrane (2) of the cells of both the distal convoluted tubule and the granular segment of the cortical collecting tubule $(3,4)$. Renal kallikrein releases lysylbradykinin or bradykinin from kininogen (5), a protein substrate that is present in the plasma, urine, and cells of the distal nephron $(6,7)$. Kinins resulting from the interaction of kallikrein and kininogen within the kidney are added to the tubular fluid of the distal nephron at sites that correspond to or are distal to the site of kallikrein release into the tubular compartment $(8,9)$. The urinary excretion rate of kinins is presumably an index of the net balance between the generation and degradation of renal kinins (10).

A relationship between vasopressin and the activity of the kallikrein-kinin system was suggested by Robertson and Conder (11) and by Fejes-Toth et al. (12), who in preliminary reports indicated that the urinary excretion of kinins increases during vasopressin infusion in man and dog. Fejes-Toth et al. (13) also demonstrated that the administration of vasopressin elevates renal kallikrein excretion in dog and rat. However, the excretion of kallikrein is not affected by lack of vasopressin in rats with hereditary diabetes insipidus (14), or by an excess of vasopressin in dogs during water deprivation (15). If vasopressin augments the activity of the renal kallikrein-kinin system, the renal excretion of kinins would be expected to increase when the level of endogenous vasopressin increases and to decrease when vasopressin decreases. Therefore, the present study in rats was designed to investigate the consequences of perturbations in vasopressin levels on the renal excretion of kinins. First, we compared the excretion rate of renal kinins in Long-Evans rats with the values in Brattleboro rats with hereditary hypothalamic diabetes insipidus (16). Second, we studied in Long-Evans rats the effects on renal kinin excretion of increases or decreases in endogenous vasopressin caused by infusion of hypertonic or isotonic solutions, respectively. Third, we evaluated the effects 
of vasopressin administration on renal kinin excretion in both diabetes insipidus rats and in Long-Evans rats during water diuresis.

\section{Methods}

\section{General procedures}

Experiments were performed in 25 male Long-Evans rats and in 21 male Brattleboro rats with hereditary hypothalamic diabetes insipidus, which were obtained from Blue Spruce Farms, Altamont, NY. Until the day of the study, the animals were kept in a temperature $\left(24^{\circ} \mathrm{C}\right)-$ and humidity (50\%)-controlled room, had free access to tap water, and were fed ad lib. a standard chow (Purina No. 5001, Ralston Purina Co., St. Louis, MO).

On the morning of the study, the rats were anesthetized with Inactin (100 mg/kg i.p.; BYK Gulden Lomberg Chemische Fabrik, Federal Republic of Germany) and placed on a thermostatically controlled animal board to maintain body temperature at $37^{\circ} \mathrm{C}$. After tracheostomy, polyethylene cannulas were placed in the right external jugular vein (PE 10) for infusions and drug administration, in the right carotid artery (PE 50) for recording of blood pressure by means of a Statham pressure transducer (P23 ID) connected to a Grass Polygraph (model 5C), and in the left ureter (PE50; 30-40 $\mu$ l dead space) for collection of urine. All incision areas were covered with Parafilm to reduce loss of fluid. After completion of surgery, infusion of fluids as indicated in each specific design was initiated, and one of four protocols was implemented after an equilibration period of at least $60 \mathrm{~min}$ from the beginning of infusion. Urine was collected in preweighted polypropylene tubes maintained at $4^{\circ} \mathrm{C}$. All urine samples were examined for contamination with blood as evidenced by the presence of hemoglobin (Hemastix test, Ames Co., Elkhart, IN). The presence of hemoglobin in one or more samples resulted in the exclusion of the experiment from the study.

\section{Experimental design}

Protocol $I$. This protocol was designed to compare the urinary excretion of kinins by Brattleboro rats with diabetes insipidus $(n=6)$ and by Long-Evans rats $(n=7)$. The animals in both groups received an intravenous infusion of $0.90 \% \mathrm{NaCl}(154 \mathrm{mM})$ at $0.16 \mathrm{ml} \mathrm{kg}^{-1} \mathrm{~min}^{-1}$ throughout the experiment. A urine sample was collected for $60 \mathrm{~min}$ after stabilization of urine flow, the volume was recorded, and the specimen was analyzed for osmolality, electrolytes, vasopressin, kininogenase activity, and kinins. After completion of the urine collection, the kidneys were removed for assay of renal kininogenase activity.

Protocol II. This protocol examined, in Long-Evans rats, the relationship between vasopressin and the renal excretion of kinins before and during infusion of $5 \% \mathrm{NaCl}(862 \mathrm{mM})$ or $0.45 \% \mathrm{NaCl}(77 \mathrm{mM})-$ $2.5 \%$ dextrose $(138 \mathrm{mM})$. Animals in both groups received an intravenous infusion of $0.9 \% \mathrm{NaCl}$ at $0.06 \mathrm{ml} \mathrm{kg}^{-1} \mathrm{~min}^{-1}$ during postsurgery equilibration and the control period. A control urine specimen was collected for $60 \mathrm{~min}$ after stabilization of urine flow. This was followed by intravenous infusion of $5 \% \mathrm{NaCl}$ at $0.18 \mathrm{ml} \mathrm{kg}^{-1} \mathrm{~min}^{-1}$ in one group of animals $(n=6)$, and of $0.45 \% \mathrm{NaCl}-2.5 \%$ dextrose at $0.64 \mathrm{ml} \mathrm{kg}^{-1}$ $\min ^{-1}$ in a second group $(n=5)$, throughout the remainder of the experiment. Another urine specimen was collected for $60 \mathrm{~min}$ after equilibration intervals of 30-60 and 60-90 $\mathrm{min}$ in the first and second groups, respectively. The control and the experimental urine samples were analyzed for volume, electrolytes, osmolality, vasopressin, kininogenase activity, and kinins.
Protocol III. This protocol examined the effects of a $5 \% \mathrm{NaCl}$ infusion on the renal kallikrein-kinin system in six diabetes insipidus rats. The animals received an intravenous infusion of $0.45 \% \mathrm{NaCl}-2.5 \%$ dextrose at $0.06 \mathrm{ml} \mathrm{kg}^{-1}$ mlin $^{-1}$ during postsurgery equilibration and the control period. A control urine specimen was collected for $60 \mathrm{~min}$ after stabilization of urine flow. This was followed by intravenous infusion of $5 \% \mathrm{NaCl}$ at $0.18 \mathrm{ml} \mathrm{kg}^{-1} \mathrm{~min}^{-1}$ throughout the remainder of the experiment. Another urine sample was collected for $60 \mathrm{~min}$ after a 30 60-min equilibration interval. The control and the experimental urine samples were analyzed for volume, electrolytes, osmolality, vasopressin, kininogenase activity, and kinins.

Protocol IV. This protocol examined the effect of vasopressin on renal kinin excretion in nine diabetes insipidus rats, and in seven LongEvans rats during volume expansion with $0.45 \% \mathrm{NaCl}-2.5 \%$ dextrose to depress endogenous vasopressin. The diabetes insipidus rats received an intravenous infusion of $0.45 \% \mathrm{NaCl}-2.5 \%$ dextrose at $0.18 \mathrm{ml} \mathrm{kg}^{-1}$ $\min ^{-1}$ throughout the experiment. The Long-Evans rats were volume expanded by intravenous infusion of $0.45 \% \mathrm{NaCl}-2.5 \%$ dextrose equivalent to $7 \%$ of the body weight delivered at $0.64 \mathrm{ml} \mathrm{kg}^{-1} \mathrm{~min}^{-1}$, followed by a maintenance infusion at $0.22 \mathrm{ml} \mathrm{kg}^{-1} \mathrm{~min}^{-1}$ throughout the experiment. A control urine sample was collected for $60 \mathrm{~min}$ after an equilibration interval of $60-\mathrm{min}$ in the diabetes insipidus rats, and of $120-150 \mathrm{~min}$ in the Long-Evans rats. This was followed in both groups of rats by intravenous infusion of arginine vasopressin (Sigma Chemical Co., St. Louis, MO) at $1.2 \mathrm{mU} / \mathrm{h}$ for $\mathbf{8 0 - 9 0 ~ m i n . ~ D u r i n g ~ v a s o p r e s s i n ~}$ infusion, a second urine sample was collected for $60 \mathrm{~min}$ after a 2030-min equilibration interval. A third urine sample was collected for $60 \mathrm{~min}$ commencing $20 \mathrm{~min}$ after cessation of the vasopressin infusion. All urine specimens in both groups of animals were analyzed for volume, electrolytes, osmolality, and kinins. The urine of the Long-Evans rats was also analyzed for kininogenase activity.

\section{Analytical procedures}

Determination of kinins in urine. Urine specimens were maintained at $4^{\circ} \mathrm{C}$ throughout the collection period to minimize any formation or degradation of kinins in vitro. In this regard we found that the kinin excretion rate measured in urine collected at $4^{\circ} \mathrm{C}(18 \pm 3 \mathrm{pg} / \mathrm{min}$ per kidney) did not differ from that measured in urine collected into 4-8 vol of ethanol $(19 \pm 4 \mathrm{pg} / \mathrm{min}$ per kidney; $n=4)$. The concentration of kinins in urine was measured by radioimmunoassay after extraction (17). A volume of urine corresponding to $\sim 80 \%$ of a 60 -min collection was acidified to $\mathrm{pH} 3.0$ with glacial acetic acid and passed through a column of octadecylsilyl silica (Sep Pak $\mathrm{C}_{18}$ cartridges, Waters Associates, Millipore Corp., Milford, MA) prewashed with methanol $(4 \mathrm{ml})$ and then with water $(12 \mathrm{ml})$; the column was then eluted successively with water $(8 \mathrm{ml}), 0.1 \mathrm{M}$ acetic acid $(4 \mathrm{ml})$, and $80 \%$ acetonitrile in $0.1 \mathrm{M}$ acetic acid $(6 \mathrm{ml})$. The acetonitrile eluate containing the kinin peptides was received into a siliconized glass vial and was subsequently evaporated under a stream of nitrogen; the residue was reconstituted before radioimmunoassay in $1.0 \mathrm{ml}$ of $0.1 \mathrm{M}$ phosphate buffer ( $\mathrm{pH} 7.4$ ) containing $0.15 \mathrm{M} \mathrm{NaCl}, 0.1 \%$ sodium azide, and $0.2 \%$ gelatin. The recovery of ${ }^{125}$ I-bradykinin-(8-tyrosine) (1,000 cpm; New England Nuclear, Boston, MA) added to each sample before extraction was $85 \pm 3 \%$; the individual recovery values served to correct the estimates of kinins in urine for losses incurred during extraction. The recovery of labeled iodobradykinin was similar to that of unlabeled bradykinin triacetate $(89 \pm 8 \%)$ added to urine samples $(0.1-1.0 \mathrm{ng} / \mathrm{ml})$ before extraction. The radioimmunoassay of kinins was performed by the method of Carretero et al. (18) with minor modifications (19), using an antibody (18) supplied by Dr. O. A. Carretero and Dr. G. Scicli (Henry Ford Hospital, Detroit, MI), 
${ }^{125}$ I-bradykinin-(8-tyrosine) as the tracer, and bradykinin triacetate as the standard. The lower limit of detection of the assay was $2 \mathrm{pg} /$ tube; the amount of bradykinin standard required to produce $50 \%$ displacement of radiolabeled kinin from antibody-binding sites was $18 \pm 2 \mathrm{pg}$. The displacement of the iodobradykinin tracer from the kinin antibodybinding sites by serially diluted samples, by Lys-bradykinin, or by MetLys-bradykinin, paralleled the displacement caused by varying amounts of the bradykinin standard. However, Lys-bradykinin and Met-Lysbradykinin have only 66 and $50 \%$ of the immunoreactivity of bradykinin, respectively. The kinin immunoreactivity extracted from urine was lost during incubation $\left(15 \mathrm{~min}, \mathrm{pH} 7.0,37^{\circ} \mathrm{C}\right)$ with carboxypeptidase $\mathrm{B}$ ( $1 \mathrm{U}$; Sigma Chemical Co.). The urinary excretion of kinins is expressed as picograms of bradykinin equivalents excreted per minute per kilogram of body weight. Intraassay variability was $11.8 \%$.

Determination of kininogenase. Kinin-generating enzyme activity in urine and in homogenates of renal cortex in $12 \mathrm{mM}$ deoxycholic acid was measured according to published procedures $(20)$ by assay of kinin generated during incubation $\left(20 \mathrm{~min}, 37^{\circ} \mathrm{C}, \mathrm{pH} 8.5\right)$ of the urine (2$10 \mu \mathrm{l})$ or tissue extract $(5 \mathrm{mg})$ with kininogen in the presence of disodium ethylenediaminetetraacetate $(10 \mathrm{mM}), 1,10$-phenanthroline $(3 \mathrm{mM})$ and SQ-20881 (10 $\mu \mathrm{g} / \mathrm{ml}$; E. R. Squibb \& Sons, Inc., Princeton, NJ) to inhibit kininases. After termination of the enzymatic reaction by heating in a boiling-water bath for $5 \mathrm{~min}$, kinins formed during the incubation were measured by radioimmunoassay (19) of samples diluted in $0.1 \mathrm{M}$ phosphate buffer ( $\mathrm{pH} 7.4$ ) containing $0.15 \mathrm{M} \mathrm{NaCl}, 0.1 \%$ sodium azide, and $0.2 \%$ gelatin. The kininogen preparation was obtained from pooled canine plasma, collected in the presence of sodium citrate $(3.1 \mathrm{mg} / \mathrm{ml})$ and hexadimethrine $(0.4 \mathrm{mg} / \mathrm{ml})$, by a procedure involving heat treatment $\left(62^{\circ} \mathrm{C}\right.$ for $\left.2 \mathrm{~h}\right)$ to inactivate kallikrein inhibitors and both kinin-forming and kinin-inactivating enzymes, ammonium sulfate fractionation (1.9 M), dialysis, and lyophilization (20). The kininogenase activity measured in the urine and the renal cortex extract resembles glandular kallikrein in that it was fully inhibited by preincubation with aprotinin $(50 \mu \mathrm{g} /$ ml; Bayer A.G., Leverkusen-Bayerwerk, Federal Republic of Germany) or with an antiserum against rat urinary kallikrein $(1 / 2,000$ dilution) provided by Dr. O. A. Carretero and Dr. A. G. Scicli. The contribution of plasma kallikrein or urinary esterase $A_{2}(21)$ to the kinin-forming activity of the urine and renal extract appears minor, since preincubation with soybean trypsin inhibitor ( $50 \mu \mathrm{g} / \mathrm{ml}$; Sigma Chemical Co.) to inhibit such enzymes (22) reduced the kininogenase activity of pooled urine and renal homogenate samples by only $6 \%$. Renal kininogenase activity is expressed as milliunits of enzyme per milligram of wet kidney weight. Kininogenase urinary excretion is expressed as milliunits of enzyme excreted per minute per kilogram of body weight. $1 \mathrm{U}$ of kininogenase is defined as the amount of enzyme that releases from canine kininogen $1 \mu \mathrm{g}$ of bradykinin equivalent per minute of incubation under specific assay conditions. The coefficient of variation of kininogenase assays in the same sample on four different days was 6.3 and $9.1 \%$ for samples of renal homogenate and urine, respectively.

Determination of vasopressin in urine. Vasopressin was extracted from urine by adsorption to an octadecylsilyl silica column, from which it was eluted with $80 \%$ acetonitrile in $0.1 \mathrm{M}$ acetic acid according to the procedure described above for kinin extraction. As vasopressin and kinins were eluted together in the acetonitrile fraction, the extraction of one urine specimen permitted the measurement of both peptides. Vasopressin was determined by radioimmunoassay as previously described (23). The U. S. Pharmacopeia posterior pituitary reference standard was used as the vasopressin standard. The lower limit of detection of the assay was $0.5 \mu \mathrm{U} /$ tube; the amount of vasopressin standard required to produce $50 \%$ displacement of radiolabeled vasopressin from antibodybinding sites was $5.0 \pm 0.3 \mu \mathrm{U}$. Average recovery of vasopressin in urine samples was $94 \pm 4 \%$; the results were not corrected for incomplete recovery. The urinary excretion of vasopressin is expressed in microunits of peptide excreted per minute per kilogram of body weight. Intraassay variability was $5.3 \%$.

Determination of electrolytes and osmolality. Sodium and potassium concentration in urine was determined by flame photometry with lithium as the internal standard. The osmolality of plasma and urine was determined by freezing-point depression.

Statistical analyses. Results are expressed throughout the text, tables, and figures as mean \pm SEM. Data were analyzed by paired or unpaired $t$ tests. The null hypothesis was rejected when the $P$ value was $<0.05$.

\section{Results}

The renal kallikrein-kinin system in Long-Evans rats and in Brattleboro rats with diabetes insipidus (Fig. 1 and Table I). The urinary excretion of immunoreactive kinins in diabetes insipidus rats $\left(24 \pm 3 \mathrm{pg} \mathrm{min}^{-1} \mathrm{~kg}^{-1}\right)$ was lower than that in LongEvans rats $\left(182 \pm 22 \mathrm{pg} \mathrm{min}^{-1} \mathrm{~kg}^{-1} ; P<0.01\right)$. However, both renal kininogenase activity and the urinary excretion of kininogenase were elevated $(P<0.05)$ in diabetes insipidus animals, relative to values in Long-Evans rats. The diabetes insipidus animals also exhibited negligible urinary excretion of immunoreactive vasopressin, reduced urine osmolality, and elevated urine flow and potassium excretion.

Relationship between vasopressin and renal kinin excretion during infusion of $5 \% \mathrm{NaCl}$ or $0.45 \% \mathrm{NaCl}-2.5 \%$ dextrose in Long-Evans rats (Fig. 2 and Table II), and 5\% $\mathrm{NaCl}$ in diabetes insipidus rats (Table III). In Long-Evans rats, the infusion of $0.45 \% \mathrm{NaCl}-2.5 \%$ dextrose at $0.64 \mathrm{ml} \mathrm{kg}^{-1} \mathrm{~min}^{-1}$ reduced the

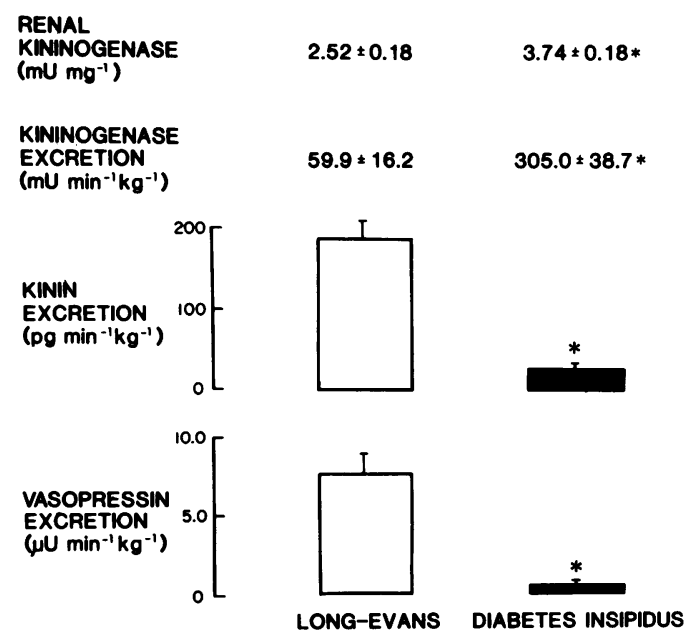

Figure 1. Renal kininogenase activity and urinary excretions of kininogenase, kinin, and vasopressin in seven Long-Evans and in six diabetes insipidus rats. Values and bars are means \pm SE. $*, P<0.05$ relative to values in Long-Evans rats (unpaired $t$-test). 
Table I. Renal Excretory Functions in Seven Long-Evans and in Six Diabetes Insipidus Rats

\begin{tabular}{lccc}
\hline & Long-Evans & $\begin{array}{l}\text { Diabetes } \\
\text { insipidus }\end{array}$ & $P$ \\
\hline $\begin{array}{l}\text { Body weight }(g) \\
\begin{array}{l}\text { Urine flow } \\
\left(\mu l \mathrm{~min}^{-1} \mathrm{~kg}^{-1}\right)\end{array}\end{array}$ & $307 \pm 12$ & $332 \pm 36$ & $>0.50$ \\
$\begin{array}{c}\text { Urine osmolality } \\
\left(\text { mosmol } / \mathrm{kg} \mathrm{H}_{2} \mathrm{O}\right)\end{array}$ & $1337 \pm 55$ & $387 \pm 13$ & $<0.001$ \\
$\begin{array}{c}\text { Sodium excretion } \\
\left(\mu e q \mathrm{~min}^{-1} \mathrm{~kg}^{-1}\right)\end{array}$ & $1.5 \pm 0.3$ & $1.3 \pm 0.3$ & $>0.60$ \\
$\begin{array}{c}\text { Potassium excretion } \\
\left(\mu e q \mathrm{~min}^{-1} \mathrm{~kg}^{-1}\right)\end{array}$ & $1.4 \pm 0.3$ & $3.7 \pm 1.0$ & $<0.05$ \\
\hline
\end{tabular}

$P$ indicates the level of significance (unpaired $t$ test). Values are means \pm SE.

urinary excretion of kinins from $163 \pm 18$ to $67 \pm 19 \mathrm{pg} \mathrm{min}^{-1}$ $\mathrm{kg}^{-1}(P<0.01)$, and the excretion of vasopressin from $17.8 \pm 4.9$ to $4.7 \pm 1.1 \mu \mathrm{U} \min ^{-1} \mathrm{~kg}^{-1}(P<0.05)$. In addition, volume expansion with $\mathrm{NaCl}$-dextrose solution reduced urine osmolality to $15 \%$ of control, while increasing urine flow by ninefold, sodium excretion by eightfold, and the urinary excretion of kininogenase by almost twofold. In contrast to the suppressing effect of the saline-dextrose solution on vasopressin and renal kinin excretion, the infusion of $5 \% \mathrm{NaCl}$ at $0.18 \mathrm{ml} \mathrm{kg}^{-1} \mathrm{~min}^{-1}$ in Long-Evans rats increased the urinary excretion of kinins from $136 \pm 37$ to $225 \pm 55 \mathrm{pg} \mathrm{min}^{-1} \mathrm{~kg}^{-1}(P<0.01)$, and the excretion of vasopressin from $14.2 \pm 2.2$ to $56.3 \pm 9.0 \mu \mathrm{U} \mathrm{min}{ }^{-1} \mathrm{~kg}^{-1}(P$ $<0.01)$. The infusion of hypertonic saline also increased urine flow by eightfold, sodium excretion by 23 -fold, and the excretion of kininogenase by over twofold. In diabetes insipidus rats, however, the infusion of $5 \% \mathrm{NaCl}$ at $0.18 \mathrm{ml} \mathrm{kg}^{-1} \min ^{-1}$ had no effects on the urinary excretions of kinins, kininogenase, or vasopressin, although it increased the flow and osmolality of urine and the excretion of sodium and potassium.

When the data on renal kinin excretion from all the animals included in protocols II and III were combined, the rate of excretion was found to correlate positively with the log of vasopressin excretion (Fig. 3; $r=0.73, P<0.01$ ) and the osmolality of the urine $(r=0.55, P<0.01)$. In contrast, the excretion of kinins did not correlate significantly with urine volume or the excretion of sodium, potassium, or kininogenase.

Effect of vasopressin infusion on renal kinin excretion (Fig. 4 and Table IV). In Long-Evans rats during volume expansion with $0.45 \% \mathrm{NaCl}-2.5 \%$ dextrose to reduce endogenous vasopressin levels, the administration of vasopressin at $1.2 \mathrm{mU} / \mathrm{h}$ i.v. increased both the urinary excretion of kinins and urine osmolality by over twofold, while reducing urine flow to $27 \%$ of control and the urinary excretion of kininogenase from $339 \pm 89$ to $122 \pm 20 \mathrm{mU} \mathrm{min}^{-1} \mathrm{~kg}^{-1}(P<0.05)$. Also in diabetes insipidus rats, vasopressin infusion increased the renal excretion of kinins and urine osmolality while decreasing urine flow.

\section{Discussion}

This study demonstrates that the urinary excretion of immunoreactive kinins in the anesthetized, surgically stressed rat varies in relation to the excretion of vasopressin irrespective of sodium excretion, and urine volume or osmolality. We base this conclusion on the following evidence. First, the excretion rate of kinins in the Brattleboro homozygous rat with diabetes insipidus due to lack of vasopressin was only $13 \%$ of the excretion rate in Long-Evans controls. Second, the rate of excretion of both kinins and vasopressin in Long-Evans rats decreased during volume expansion with $0.45 \% \mathrm{NaCl}-2.5 \%$ dextrose to reduce vasopressin secretion. Conversely, the excretion rate of both peptides increased during infusion of hypertonic saline, which increases vasopressin secretion. Third, the excretion of kinins during conditions that depress or promote vasopressin secretion did not correlate consistently with variables other than the ex-

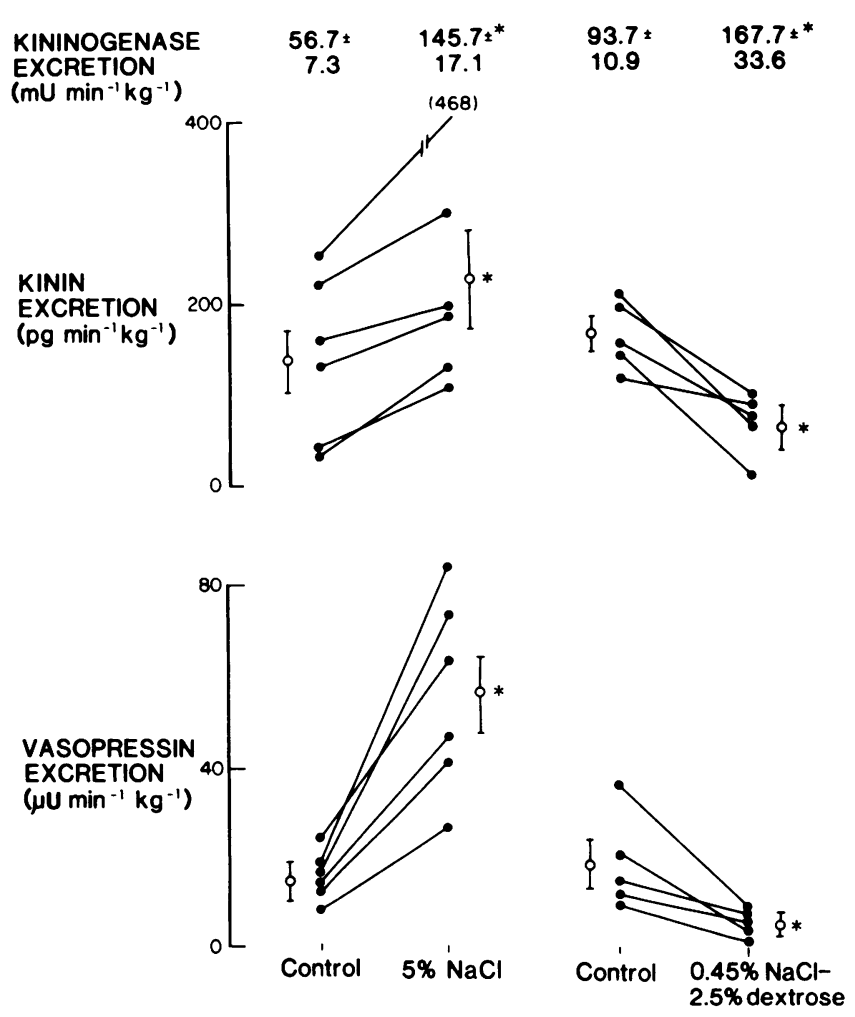

Figure 2. Urinary excretions of vasopressin, kinin, and kininogenase in Long-Evans rats before and during infusion of $5 \% \mathrm{NaCl}(0.18 \mathrm{ml}$ $\mathrm{kg}^{-1} \mathrm{~min}^{-1}$ i.v., $n=6$ ), or volume expansion with $0.45 \% \mathrm{NaCl}-2.5 \%$ dextrose $\left(0.64 \mathrm{ml} \mathrm{kg}^{-1} \mathrm{~min}^{-1}\right.$ i.v., $\left.n=5\right)$. Values and $\circ$, means $\pm \mathrm{SE}$; -, individual results. *, $P<0.05$ relative to control values before treatment (paired $t$ test). 
Table II. Renal Effects of 5\% NaCl Infusion (0.18 $\mathrm{ml} \mathrm{kg}^{-1} \mathrm{~min}^{-1}$ i.v.), and of Volume Expansion with 0.45\% NaCl-2.5\% Dextrose (0.64 $\mathrm{ml} \mathrm{kg}^{-1} \mathrm{~min}^{-1}$ i.v.) in Long-Evans Rats

\begin{tabular}{|c|c|c|c|c|c|c|}
\hline & \multicolumn{3}{|c|}{$5 \% \mathrm{NaCl}(n=6 ;$ body wt $=316 \pm 18 \mathrm{~g})$} & \multicolumn{3}{|c|}{$0.45 \% \mathrm{NaCl}-2.5 \%$ Dextrose $(n=5 ;$ body $\mathrm{wt}=272 \pm 11 \mathrm{~g})$} \\
\hline & Control* & Treatment & $\boldsymbol{P}$ & Control* & Treatment & $P$ \\
\hline \multicolumn{7}{|l|}{ Urine flow } \\
\hline$\left(\mu l \min ^{-1} \mathrm{~kg}^{-1}\right)$ & $22.8 \pm 4.1$ & $194.7 \pm 64.0$ & $<0.05$ & $32.6 \pm 4.7$ & $300.8 \pm 57.9$ & $<0.01$ \\
\hline \multicolumn{7}{|l|}{ Urine osmolality } \\
\hline ( $\mathrm{mosmol} / \mathrm{kg} \mathrm{H}_{2} \mathrm{O}$ ) & $1206 \pm 175$ & $1204 \pm 180$ & $>0.90$ & $1482 \pm 180$ & $230 \pm 29$ & $<0.01$ \\
\hline \multicolumn{7}{|l|}{ Sodium excretion } \\
\hline$\left(\mu e q \min ^{-1} k^{-1}\right)$ & $2.3 \pm 0.9$ & $53.6 \pm 20.3$ & $<0.05$ & $2.2 \pm 0.2$ & $17.5 \pm 4.2$ & $<0.01$ \\
\hline \multicolumn{7}{|l|}{ Potassium excretion } \\
\hline$\left(\mu e q \min ^{-1} \mathrm{~kg}^{-1}\right)$ & $4.8 \pm 2.0$ & $7.7 \pm 2.3$ & $>0.20$ & $4.7 \pm 0.9$ & $4.9 \pm 1.3$ & $>0.90$ \\
\hline
\end{tabular}

$P$ indicates the level of significance (paired $t$ test); values are means \pm SE. * Animals in both groups were infused with $0.90 \% \mathrm{NaCl}(0.06 \mathrm{ml}$ $\mathrm{kg}^{-1} \mathrm{~min}^{-1}$ i.v.) during the control period.

cretion of vasopressin. For example, sodium excretion increased during infusion of $5 \% \mathrm{NaCl}$ in both Long-Evans and diabetes insipidus rats, but the excretion of kinins rose in Long-Evans rats only. Urine flow increased in Long-Evans rats both during volume expansion with $0.45 \% \mathrm{NaCl}-2.5 \%$ dextrose and during infusion of $5 \% \mathrm{NaCl}$, but urinary kinin excretion fell in the first instance and increased in the second. Urine osmolality and kinin excretion data from protocols II and III are correlated positively, yet urine osmolality increased without associated changes in kinin excretion during infusion of hypertonic $\mathrm{NaCl}$

Table III. Effects of $5 \% \mathrm{NaCl}$ Infusion $\left(0.18 \mathrm{ml} \mathrm{kg}^{-1} \mathrm{~min}^{-1}\right.$ i.v.) in Six Diabetes Insipidus Rats*

\begin{tabular}{|c|c|c|c|}
\hline & Controlł & Treatment & $p$ \\
\hline 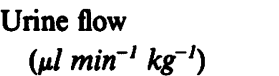 & $90.8 \pm 13.3$ & $292.8 \pm 37.4$ & $<0.01$ \\
\hline $\begin{array}{l}\text { Urine osmolality } \\
\left.\text { ( } \mathrm{mosmol} / \mathrm{kg} \mathrm{H} \mathrm{H}_{2} \mathrm{O}\right)\end{array}$ & $266 \pm 37$ & $591 \pm 139$ & $<0.05$ \\
\hline $\begin{array}{l}\text { Sodium excretion } \\
\left(\mu e q \mathrm{~min}^{-1} \mathrm{~kg}^{-1}\right)\end{array}$ & $1.5 \pm 1.0$ & $29.2 \pm 3.7$ & $<0.01$ \\
\hline $\begin{array}{l}\text { Potassium excretion } \\
\text { ( } \mu \text { eq } \mathrm{min}^{-1} \mathrm{~kg}^{-1} \text { ) }\end{array}$ & $2.4 \pm 0.5$ & $9.4 \pm 1.1$ & $<0.01$ \\
\hline $\begin{array}{l}\text { Vasopressin excretion } \\
\left(\mu U \mathrm{~min}^{-1} \mathrm{~kg}^{-1}\right)\end{array}$ & $0.7 \pm 0.2$ & $0.9 \pm 0.2$ & $>0.30$ \\
\hline $\begin{array}{l}\text { Kininogenase excretion } \\
\left(m U \mathrm{~min}^{-1} \mathrm{~kg}^{-1}\right)\end{array}$ & $321 \pm 75$ & $292 \pm 38$ & $>0.50$ \\
\hline $\begin{array}{l}\text { Kinin excretion } \\
\qquad\left(p g \mathrm{~min}^{-1} \mathrm{~kg}^{-1}\right)\end{array}$ & $36 \pm 18$ & $32 \pm 13$ & $>0.70$ \\
\hline
\end{tabular}

* Mean body weight, $312 \pm 14 \mathrm{~g} ; P$ indicates the level of significance (paired $t$ test). Values are means \pm SE.

¥ Animals received an infusion of $0.45 \% \mathrm{NaCl}-2.5 \%$ Dextrose $(0.06$

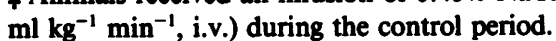

in the diabetes insipidus rat. Hence, it appears that during experimental conditions that alter vasopressin secretion, sodium excretion, urine volume, and osmolality, the urinary excretion of kinins was consistently related to the rate of vasopressin excretion only.

Two preliminary reports suggest an influence of vasopressin on renal kinin excretion. Fejes-Toth et al. (12) found an increased urinary excretion of kinins during infusion of vasopressin in dogs. Robertson and Conder (11) found that the rate of kinin excretion is depressed by water loading in man and is increased by Pitressin in patients with familial neurogenic diabetes insipi-

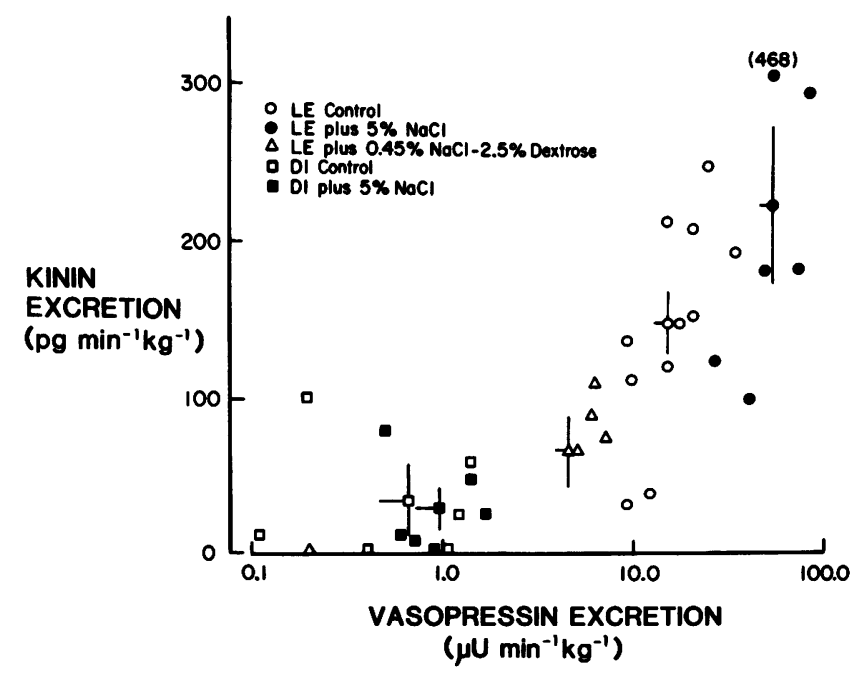

Figure 3. Relationship between the urinary excretions of vasopressin and kinins in Long-Evans rats before (0) and during infusion of 5\% $\mathrm{NaCl}(\bullet)$ or volume expansion with $0.45 \% \mathrm{NaCl}-2.5 \%$ dextrose $(\Delta)$, and in diabetes insipidus rats before ( $\square$ ) and during infusion of $5 \%$ $\mathrm{NaCl}(\boldsymbol{\bullet})$. 
DIABETES INSIPIDUS RATS

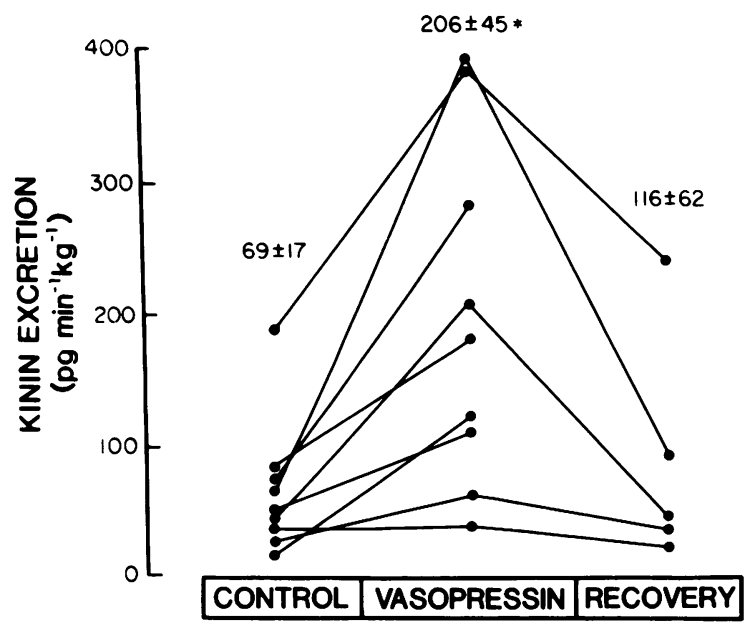

LONG-EVANS RATS

DURING VOLUME EXPANSION

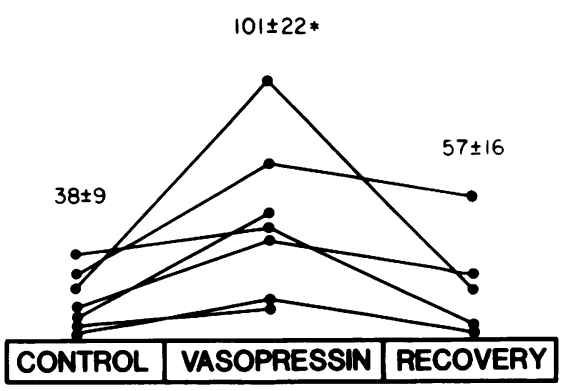

Figure 4. Urinary kinin excretion before, during, and after infusion of vasopressin $(1.2 \mathrm{mU} / \mathrm{h} \mathrm{i.v.})$ in nine diabetes insipidus rats, and in seven Long-Evans rats during volume expansion with $0.45 \% \mathrm{NaCl}-2.5 \%$ dextrose. Values are means $\pm \mathrm{SE}$, and $\bullet$, individual results. *, $P$ $<0.05$ relative to control values before treatment (paired $t$ test). dus. In the present study, we observed that infusion of vasopressin elevates the excretion rate of kinins in both diabetes insipidus rats and Long-Evans rats during suppression of endogenous vasopressin secretion by volume expansion with $0.45 \% \mathrm{NaCl}-$ $2.5 \%$ dextrose. Therefore, to the extent that changes in vasopressin excretion reflect primary alterations in the circulating levels of the hormone, our finding that the excretion of kinins varies in relation to the excretion of vasopressin suggests regulation of the renal kallikrein-kinin system by the antidiuretic peptide.

A priori, the mechanism of the vasopressin effect in increasing kinin excretion may involve enhancement of the activity of the renal kallikrein-kinin system, owing to reduced degradation or to augmented generation of kinins within the kidney. However, evidence that vasopressin inhibits kinin-inactivating mechanisms is lacking, and that it promotes renal kallikrein activity is conflicting. For example, Fejes-Toth et al. (13) reported an augmented urinary excretion of a kallikrein-like esterase during short term infusion of vasopressin in anesthetized rats and dogs during water diuresis. In contrast, Bonner et al. (14) found that the excretion of a kallikrein-like amidase by both Long-Evans and diabetes insipidus rats is not affected by treatment with vasopressin for $3 \mathrm{~d}$ (14), a finding which Fejes-Toth et al. (24) confirmed recently in the diabetes insipidus rat. In the present study we found that the excretion of kallikrein-like kininogenase diminished during vasopressin infusion in Long-Evans rats made diuretic by volume expansion with $0.45 \% \mathrm{NaCl}-2.5 \%$ dextrose. We also found that the excretion of kininogenase in Long-Evans

Table IV. Effects of Vasopressin (1.2 mU/h i.v.) in Diabetes Insipidus Rats, and in Long-Evans Rats during Volume Expansion with $0.45 \% \mathrm{NaCl}-2.5 \%$ Dextrose

\begin{tabular}{|c|c|c|c|c|c|c|}
\hline & \multicolumn{3}{|c|}{$\begin{array}{c}\text { Diabetes insipidus } \\
(n=9 ; \text { body weight }=289 \pm 11 \mathrm{~g})\end{array}$} & \multicolumn{3}{|c|}{$\begin{array}{l}\text { Long-Evans during volume expansion } \\
\qquad(n=7 ; \text { body weight }=383 \pm 22 \mathrm{~g})\end{array}$} \\
\hline & Control & Vasopressin & Recovery & Control & Vasopressin & Recovery \\
\hline \multicolumn{7}{|l|}{ Urine flow } \\
\hline$\left(\mu l \mathrm{~min}^{-1} \mathrm{~kg}^{-1}\right)$ & $219.6 \pm 31.1$ & $90.7 \pm 17.8^{*}$ & $232.7 \pm 47.4$ & $390.0 \pm 66.9$ & $105.4 \pm 28.9^{*}$ & $205.7 \pm 35.5$ \\
\hline \multicolumn{7}{|l|}{ Urine osmolality } \\
\hline$\left(\mathrm{mosmol} / \mathrm{kg} \mathrm{H}_{2} \mathrm{O}\right)$ & $253 \pm 38$ & $980 \pm 141^{*}$ & $222 \pm 69$ & $359 \pm 61$ & $949 \pm 70^{*}$ & $596 \pm 35$ \\
\hline \multicolumn{7}{|l|}{ Sodium excretion } \\
\hline$\left(\mu e q \mathrm{~min}^{-1} \mathrm{~kg}^{-1}\right)$ & $1.2 \pm 0.5$ & $4.3 \pm 1.7^{*}$ & $1.8 \pm 0.9$ & $28.6 \pm 6.8$ & $25.8 \pm 9.2$ & $26.8 \pm 6.6$ \\
\hline \multicolumn{7}{|l|}{ Potassium excretion } \\
\hline$\left(\mu e q \min ^{-1} k^{-1}\right)$ & $4.4 \pm 1.3$ & $9.8 \pm 3.0$ & $4.1 \pm 1.4$ & $12.6 \pm 2.1$ & $11.2 \pm 3.0$ & $11.9 \pm 1.6$ \\
\hline \multicolumn{7}{|l|}{ Blood pressure } \\
\hline$(\mathrm{mmHg})$ & $111 \pm 7$ & $115 \pm 9$ & $107 \pm 8$ & $145 \pm 6$ & $140 \pm 6$ & $138 \pm 10$ \\
\hline
\end{tabular}

Values are means \pm SE. ${ }^{*} P<0.05$ relative to control (paired $t$ test). 
rats during infusion of hypertonic saline to increase vasopressin secretion, or volume expansion with isotonic saline-dextrose solution to depress vasopressin secretion, varied with urine flow rather than in relation to the excretion of vasopressin. However, the excretion of kininogenase during infusion of hypertonic saline in diabetes insipidus rats did not increase despite significant augmentation of urine flow. Other investigators have also noted that augmentation of kallikrein excretion accompanies the early but not the late phase of the diuretic response to volume expansion or mannitol in rats, and attributed the increase in excretion to "washout" of the enzyme from the luminal surface of kallikrein-containing cells in the distal nephron $(25,26)$. The disparity in results regarding the effects of vasopressin treatment on kallikrein excretion may relate to differences in the specificity of the kallikrein assay procedures and in the experimental conditions.

The present study reveals no consistent association between the urinary excretions of kininogenase and kinins, a finding that is in agreement with reports from others (27-28). Augmentation of kininogenase excretion was associated with increased kinin excretion in Long-Evans rats receiving an infusion of hypertonic saline. In contrast, the augmented kininogenase excretion exhibited by diabetes insipidus rats and by Long-Evans rats during volume expansion with $0.45 \% \mathrm{NaCl}-2.5 \%$ dextrose was accompanied by reduced excretion of kinins. Conversely, reduction of kininogenase excretion was associated with augmentation of kinin excretion in rats receiving an infusion of vasopressin. From these observations we conclude that increased urinary kinin excretion during conditions of elevated vasopressin levels in the rat is not related to the excretion of kininogenase. However, one must keep in mind that in vitro estimates of kininogenase in the urine and renal tissue have at best only limited value as indices of renal kinin generation in vivo. Besides kallikrein, the generation of renal kinins in vivo may depend on the availability of kininogen (7), the concentration of kallikrein inhibitors (29), the $\mathrm{pH}$ (30), and electrolyte composition of the renal environment $(31,32)$. Whether vasopressin promotes renal kinin excretion by influencing one or more of such factors is not known. In this regard, one must consider the possibility that the vasopressin-renal kinin relationship is merely an incidental expression of renal function variations elicited by vasopressin.

Complementing our finding that the excretion rate of renal kinins varies with the level of vasopressin, there are reports suggesting that the effects of vasopressin on water transport are modulated by kinins. For example, bradykinin was found to decrease vasopressin-stimulated water flow in the amphibian urinary bladder (33) and to promote the excretion of free water in mammals (10). However, the results of studies on the effects of the kallikrein inhibitor aprotinin on the amphibian bladder response to vasopressin are conflicting. Aprotinin potentiated the water flow response induced by vasopressin in one study (34) but had no effect in another study (35). In addition, in a recent study (24) the antidiuretic action of vasopressin in diabetes insipidus rats was not modified by pretreatment with aprotinin. Therefore, the significance of the vasopressin-kinin relationship with regard to water reabsorption in the distal nephron is not established as yet. The significance of the vasopressin-kinin relationship with regard to renal hemodynamics and sodium excretion is undetermined also. It is of interest to note, however, that vasopressin may either decrease or increase renal blood flow depending on dosage and the state of hydration $(36,37)$. Hence, to the extent that kinins produce renal vasodilation (10), the vasopressin-induced elevation of renal blood flow may be an expression of increased renal kinin levels.

In conclusion, the present study in Long-Evans rats and in Brattleboro rats with diabetes insipidus demonstrates that the urinary excretion of immunoreactive kinins varies in relation to the level of vasopressin, irrespective of urine volume and osmolality and of the urinary excretion of sodium and kininogenase. The results of the study implicate vasopressin in the regulation of the renal kallikrein-kinin system.

\section{Acknowledgments}

This work was supported by U. S. Public Health Service grants HL 18579, AM-28171, and HL-19209, and by a grant from the American Heart Association, Tennessee Affiliate.

\section{References}

1. Ward, P. E., E. G. Erdos, C. D. Gedney, R. M. Dowben, and R. C. Reynolds. 1976. Isolation of membrane-bound renal enzymes that metabolize kinins and angiotensins. Biochem. J. 157:643-650.

2. Yamada, K., W. W. Schulz, D. S. Page, and E. G. Erdos. 1981. Kallikrein and prekallikrein in the basolateral membrane of rat kidney tubules. Hypertension. 3(Suppl. II):II-59-II-64.

3. Omata, K., O. A. Carretero, A. G. Scicli, and B. A. Jackson. 1982. Localization of active and inactive kallikrein (kininogenase activity) in the microdissected rabbit nephron. Kidney Int. 22:602-607.

4. Proud, D., M. A. Knepper, and J. J. Pisano. 1983. Distribution of immunoreactive kallikrein along the rat nephron. Am. J. Physiol. 244:F510-F517.

5. Alhenc-Gelas, F., J. Marchetti, J. Allegrini, P. Corvol, and J. Menard. 1981. Measurement of urinary kallikrein activity: species differences in kinin production. Biochim. Biophys. Acta. 677:477-481.

6. Pisano, J. J., J. Corthorn, K. Yates, and J. V. Pierce. 1978. The kallikrein-kinin system in the kidney. Contrib. Nephrol. 12:116-125.

7. Proud, D., M. Perkins, J. V. Pierce, K. N. Yates, P. F. Highet, P. L. Herring, M. M. Mark, R. Bahu, F. Carone, and J. J. Pisano. 1981. Characterization and localization of human renal kininogen. J. Biol. Chem. 256:10634-10639.

8. Scicli, A. G., R. Gandolf, and O. A. Carretero. 1978. Site of formation of kinins in the dog nephron. Am. J. Physiol. 234:F36-F40.

9. Scicli, A. G., O. A. Carretero, A. Hampton, P. Cortes, and N. G. Oza. 1976. Site of kininogenase secretion in the dog nephron. Am. J. Physiol. 230:533-536.

10. Nasjletti, A., J. Colina-Chourio, and J. C. McGiff. 1975. Disappearance of bradykinin in the renal circulation of dogs: effects of kininase inhibition. Circ. Res. 37:59-65.

11. Robertson, G. L., and M. L. Conder. 1980. The regulation of 
urinary kinin excretion. In Hormonal Regulation of Sodium Excretion. B. Lichardus, R. W. Schrier, and J. Ponec, editors. Elsevier/NorthHolland Biomedical Press, Amsterdam. 239-248.

12. Fejes-Toth, G., T. Zahajszky, and J. Filep. 1982. Effect of vasopressin on the renal kallikrein-kinin system. Agents Actions. (Suppl.) 9:491-495.

13. Fejes-Toth, G., T. Zahajszky, and J. Filep. 1980. Effect of vasopressin on renal kallikrein excretion. Am. J. Physiol. 239:F388-F392.

14. Bonner, G., W. Rascher, G. Speck, M. Marin-Grez, and F. Gross. 1981. The renal kallikrein-kinin system in Brattleboro rats with hereditary hypothalamic diabetes insipidus. Acta Endocrinol. 98:36-42.

15. Zucker, A., A. Nasjletti, and E. G. Schneider. 1983. Effect of water deprivation on urinary excretion of $\mathrm{PGE}_{2}$ in the dog. Am. J. Physiol. 245: R329-R333.

16. Valtin, H. 1976. Animal model: hereditary hypothalamic diabetes insipidus in the Brattleboro strain of rat. Am. J. Pathol. 83:633-636.

17. Powers, C. A., and A. Nasjletti. 1983. A kininogenase resembling glandular kallikrein in the rat pituitary pars intermedia. Endocrinology. 112:1194-1200.

18. Carretero, O. A., N. B. Oza, A. Piwonska, T. Ocholik, and A. G. Scicli. 1976. Measurement of urinary kallikrein activity by kinin radioimmunoassay. Biochem. Pharmacol. 25:2265-2270.

19. Powers, C. A., and A. Nasjletti. 1982. A novel kinin-generating protease (kininogenase) in the porcine anterior pituitary. J. Biol. Chem. 257:5594-5600.

20. Nasjletti, A., J. C. McGiff, and J. Colina-Chourio. 1978. Interrelations of the renal kallikrein-kinin system and renal prostaglandins in the conscious rat. Influence of mineralocorticoids. Circ. Res. 43:799_ 807.

21. McPartland, R. P., D. L. Sustarsic, and J. P. Rapp. 1981. Evidence for an androgen-dependent urinary arginine esterase in the rat: separation from other urinary arginine esterases including kallikrein. Endocrinology. 108:1634-1638.

22. Chao, J. 1983. Purification and characterization of rat urinary esterase A, a plasminogen activator. J. Biol. Chem. 258:4434-4439.

23. Crofton, J. T., L. Share, B. C. Wong, and R. E. Shade. 1980. Pressor responsiveness to vasopressin in the rat with DOC-salt hypertension. Hypertension. 2:424-431.

24. Fejes-Toth, G., J. C. Frolich, and A. Naray-Fejes-Toth. 1983.
Effect of aprotinin on the renal response to vasopressin in diabetes insipidus rats. J. Physiol. (Lond.). 339:585-590.

25. Marks, E. S., M. Frech, D. Proud, and H. R. Keiser. 1982. Effect of alterations in extracellular fluid volume on urinary kallikrein in the conscious rat. Hypertension. 4:625-633.

26. Bonner, G., M. Marin-Grez, D. Beck, M. Deeg, and F. Gross. 1981. Changes in renal and urinary kallikrein activity by mannitolinduced osmotic diuresis. Clin. Sci. (Lond.). 61:47-51.

27. Vinci, J. M., R. M. Zusman, J. L. Isso, R. E. Bowden, D. Horwitz, J. J. Pisano, and H. R. Keiser. 1979. Human urinary and plasma kinins. Circ. Res. 44:228-237.

28. Olsen, U. B. 1980. Changes of urinary kallikrein and kinin excretions induced by adrenalin infusion in conscious dogs. Scand. J. Clin. Lab. Invest. 40:173-178.

29. Geiger, R., and K. Mann. 1976. A kallikrein-specific inhibitor in rat kidney tubules. Hoppe-Seyler's Z. Physiol. Chem. 357:553-558.

30. Diaz, M., O. A. Carretero, and A. G. Scicli. 1980. The effect of urinary pH on intrarenal formation of kinins. Physiologist. 23(4):179. (Abstr.)

31. Lieberthal, W., N. B. Oza, D. B. Bernard, and N. G. Levinsky. 1982. The effect of cations on the activity of human urinary kallikrein. J. Biol. Chem. 257:10827-10830.

32. Chao, J., S. Tanaka, and H. S. Margolius. 1983. Inhibitory effects of sodium and other monovalent cations on purified versus membranebound kallikrein. J. Biol. Chem. 258:6461-6465.

33. Furtado, M. R. F. 1971. Inhibition of the permeability response to vasopressin and oxytocin in the toad bladder. Effect of bradykinin, kallidin, eledoisin and physalamine. J. Membr. Biol. 4:167-178.

34. Carvounis, C. P., G. Carvounis, and L. A. Arbeit. 1981. Role of the endogenous kallikrein-kinin system in modulating vasopressinsimulated water flow and urea permeability in the toad urinary bladder. J. Clin. Invest. 67:1792-1796.

35. Orce, G., G. Castillo, and H. S. Margolius. 1980. Inhibition of short-circuit current in toad urinary bladder by inhibitors of glandular kallikrein. Am. J. Physiol. 239:F459-F465.

36. Fejes-Toth, G., A. Magyar, and J. Walter. 1977. Renal response to vasopressin after inhibition of prostaglandin synthesis. Am. J. Physiol. 232:F416-F423.

37. Oliver, J. A., R. R. Sciacca, G. Le Cren, and P. J. Cannon. 1982. Modulation by prostaglandins of the renal vascular action of arginine vasopressin. Prostaglandins. 24:641-656. 